\title{
Peningkatan Kemampuan Berhitung Siswa Kelas II Dengan Menggunakan Sempoa Aritmatika Di Sekolah Dasar
}

\author{
Hanifatul Rahmi ${ }^{1}$, Juni Saputra ${ }^{2}$, Welly Desriati ${ }^{3}$, Fatmawati ${ }^{4}$ \\ ${ }^{1,2,3}$ Program Studi Teknik Industri, Sekolah Tinggi Teknologi Dumai, Indonesia \\ ${ }^{4}$ SDN 001 Rimba Sekampung, Dumai, Indonesia \\ Email: ${ }^{1}$ aorrariza89@gmail.com, ${ }^{2}$ junisaputr4@gmail.com, ${ }^{3}$ wellydesriati@ gmail.com, \\ ${ }^{4}$ fatmawati15@gmail.com
}

\section{INFORMASI ARTIKEL}

\section{Data artikel:}

Naskah masuk,12 Februari 2020

Direvisi, 21 Agustus 2020

Diterima, 24 Agustus 2020

Kata Kunci:

Kemampuan Berhitung

Sempoa

Aritmatika

\section{ABSTRAK}

Abstract- The Community Service Program (PPM) which is carried out aims to improve the ability of Grade II students in Arithmetic using Sempoa media. Observation results at SDN 001 Rimba Sekampung Devotion to the mathematics learning community using this abacus media to improve students' numeracy skills. The material taught is Reading abacus beads, Teaching the sum of units, tens and hundreds with an abacus, Teaching subtraction units, tens and hundreds with an abacus This activity was carried out Monday through Tuesday, 28 and 29 January 2020, starting at 10:00 until 12.00 West Indonesian Time. This activity begins by providing a pre-test (pretest) to determine the ability to count the participants and a final test (posttest) at the end to determine the final ability after giving the material. The average value of the initial test is 6.5 and the final test is 8.9

Abstrak - Program Pengabdian Pada Masyarakat (PPM) yang dilakukan bertujuan untuk meningkatkan kemampuan siswa kelas II dalam Aritmatika dengan menggunakan media Sempoa. Hasil observasi di SDN 001 Rimba Sekampung Pengabdian pada masyarakat pembelajaran matematika menggunakan media sempoa ini untuk meningkatkan kemampuan berhitung siswa. Materi yang diajarkan adalah Membaca manik sempoa, Mengajarkan penjumlahan satuan, puluhan dan ratusan dengan sempoa, Mengajarkan pengurangan satuan, puluhan dan ratusan dengan sempoa. Kegiatan ini dilaksanakan hari Senin sampai Selasa, tanggal 28 dan 29 Januari 2020, dimulai pada pukul 10.00 sampai 12.00 WIB. Kegiatan ini diawali dengan memberikan tes awal (pretest) untuk mengetahui kemampuan berhitung para peserta dan tes akhir (posttest) pada akhir untuk mengetahui kemampuan akhir setelah pemberian materi. Nilai rata-rata tes awal adalah 6,5 dan tes akhir sebesar 8,9. 


\section{Korespondensi:}

\section{Hanifatul Rahmi}

Program Studi Teknik Industri, Sekolah Tinggi Teknologi Dumai

Jl. Utama Karya Bukit Batrem II Dumai, 28811, Riau, Indonesia

\section{PENDAHULUAN}

Pembelajaran di sekolah dasar diwarnai dengan perbedaan karakter dan gaya belajar dari setiap siswa. Mempelajari matematika adalah penting karena dalam kehidupan seharihari, kita tidak boleh mengelak dari aplikasi matematika bukan itu saja matematika juga mampu mengembangkan kesadaran tentang nilai-nilai yang secara esensial (Anugrahana, 2019). Salah satu pengharapan dari pembelajaran di sekolah dasar adalah siswa memiliki pengetahuan dan kemampuan Kemampuan yang perlu dikembangkan salah satunya adalah kemampuan berhitung.

Menurut Naga (Romlah, M., Kurniah, 2016) kemampuan berhitung adalah upaya pengenalan matematika yang berkenaan dengan sifat dan hubungan bilangan-bilangan nyata dan dengan perhitungan mereka terutama menyangkut penjumlahan, pengurangan, perkalian dan pembagian merupakan operasi bilangan yang sangat dasar. Sejalan dengan pendapat (Fatmawati, 2014) Kemampuan berhitung anak pada usia 7 sampai 11 tahun berada pada tahapan operasional konkret. Pada usia ini anak perlu dijembatani dengan sebuah media pembelajaran agar dapat mudah memahami materi operasi hitung yang disampaikan oleh guru.

Operasi hitung merupakan salah satu pembelajaran matematika yang wajib dibahas pada sekolah dasar. Penjumlahan dan pengurangan pada bilangan puluhan dan ratusan adalah materi yang dibahas pada kelas II SD. Materi pengurangan bagi sebagian siswa terasa sulit. Hal tersebut berdasarkan hasil observasi di SDN 001 Rimba Sekampung siswa mengalami kesulitan dalam menyelesaikan persoalan mengurangi. Sebagai contoh sebagian siswa tidak dapat menyelesaikan pengurangan antara empat puluh dua dikurangi tiga belas. Sebesar 35\% siswa menjawab 31. Berdasarkan hasil wawancara dengan guru kelas II dalam pembelajaran matematika siswa masih ada yang menggunakan alat bantu seperti sempoa dengan jumlah satu tiangnya sepuluh. Beberapa siswa masih belum terbiasa dengan konsep teknik bersusun yang diajarkan oleh guru.

Dari uraian di atas dapat dikembangkan ide-ide kreatif yang diharapkan dapat diaplikasikan kepada siswa dalam pengembangan kemampuan berhitung khususnya pengurangan. Ada beberapa metode hitung yang mengajarkan proses berhitung dengan logika, tetapi tidak menggunakan simbol matematika sebagai penjelasannya, seperti jarimatika, yang menggunakan bantuan tangan, atau sempoa dengan bantuan manikmanik ala china (Universitas Negeri Semarang. Lembaga Pengabdian Kepada Masyarakat. \& Wijayanti, 2008). Salah satu media pembelajaran berhitung yang dapat digunakan adalah sempoa (aritmatika) atau dikenal dengan Abacus. Sempoa merupakan singkatan dari sistem edukasi mengoptimalkan potensi otak anak. Dengan kata lain bahwa banyak berlatih sempoa dapat mengoptimalkan potensi otak yang dimiliki oleh anak. Sempoa ini terdiri dari 5 manis pada setiap tiangnya. Empat manik pada bagian bawah bernilai satu dan satu manik di atas bernilai lima. Diantara kelompok manis atas dan bawah dibatasi oleh garis nilai. Jika tidak ada manik yang menempel pada garis nilai maka kondisi tersebut disebut kondisi nol. Cara bermain sempoa dengan menggerakkan manik ke atas dan ke bawah hal ini dapat merangsang daya fikir otak anak (Dianto, 2018) .

Media sempoa memiliki banyak manfaat yang terkandung saat siswa menggunakannya yaitu : 1) sempoa dapat mengoptimalkan fungsi kerja otak kanan dan otak kiri karena selain anak konsentrasi dalam berhitung anak juga akan menggunakan imajinasi dan logikanya. 2) melatih daya imajinasi dan kreatifitas, logika, sistematika berfikir, daya konsentrasi. 3) meningkatkan kecepatan, 
ketepatan, dan ketelitian dalam berfikir. 4) menjadi lebih sensitif terhadap aransemen spasial akibat pengaruh dari membayangkan sempoa dalam otak. 5) anak akan mengingat dengan apa yang dicarinya lewat sempoa (Nurfiyanti, 2019)

Dengan demikian perlu diadakan Pelatihan Peningkatan Kemampuan Aritmatika Siswa Kelas II dengan menggunakan Sempoa Aritmatika di SDN 001 Rimba Sekampung Kota Dumai.

\section{METODE PELAKSANAAN}

Pengabdian masyarakat ini dilaksanakan untuk siswa di SD 001 Rimba Sekampung Kota Dumai di jln. Semangka kel. Dumai Barat. Jumlah pesertanya adalah 22 orang siswa. Materi pelatihan adalah dengan menggunakan alat peraga sempoa.

Langkah-langkah kegiatan yang dilakukan dalam pelaksaan pengabdian ini adalah:

a. Melakukan analisis permasalahan yang terjadi pada siswa kelas II dalam berhitung

b. Persiapan sarana dan prasarana (proyektor)

c. Memperbanyak modul

d. Persiapan tempat kegiatan

e. Mengadakan pretes

f. Mempresentasikan kepada siswa tentang cara membaca manik sempoa

g. Mengajarkan penjumlahan dengan menggunakan sempoa

h. Membagikan modul dan mengerjakannya

i. Menyampaikan materi pengurangan dengan sempoa

j. Mengerjakan modul pengurangan dengan sempoa

k. Mengadakan posttest untuk melihat hasil dari pembelajaran yang telah berlangsung

1. Penutupan Faktor pendukung dan penghambat

a. Faktor pendukung

1) Siswa baru menggunakan sempoa sehingga gerakan tangan masih belum terbiasa.

2) Siswa belum terbiasa menggunakan jempol dalam penjumlahan dan pengurangan dengan menggunakan telunjuk b. Faktor penghambat adalah alokasi waktu terbatas dan sempoa yang sulit ditemukan di daerah Dumai.

\section{HASIL DAN PEMBAHASAN}

Judul kegiatan pengabdian ini adalah "Peningkatan kemampuan berhitung siswa dengan menggunakan sempoa aritmatika". Materi yang disampaikan dalam pelatihan ini adalah:
a. Membaca manik sempoa
b. Mengajarkan penjumlahan satuan, puluhan dan ratusan dengan sempoa

c. Mengajarkan pengurangan satuan, puluhan dan ratusan dengan sempoa

Pada kegiatan ini materi disampaikan oleh tiga orang dosen yang dibantu dengan tiga orang mahasiswa lainnya yang berpartisipasi aktif mengajarkan peserta. Penyampaian materi dilakukan dengan menampilkan slide dan video di papan tulis. Selain itu, peserta juga diberikan modul latihan. Setelah dilaksanakannya pelatihan, hasil yang didapatkan ialah Siswa dengan mudah melakukan penjumlahan dan pengurangan satuan, puluhan dan ratusan. Program pengabdian masyarakat ini disambut baik oleh Kepala Sekolah Ibu Sulasteri, S,Pd. Dan Ibu Fatmawati, S.Pd selaku guru Wali Kelas yang ikut mendampingi kegiatan pengabdian ini

Kegiatan ini diawali dengan memberikan tes awal (pretest) untuk mengetahui kemampuan berhitung para peserta dan tes akhir (posttest) pada akhir untuk mengetahui kemampuan akhir setelah pemberian materi. Nilai rata-rata tes awal siswa kelas II SDN 001 adalah 6,5 dan tes akhir sebesar 8,9.

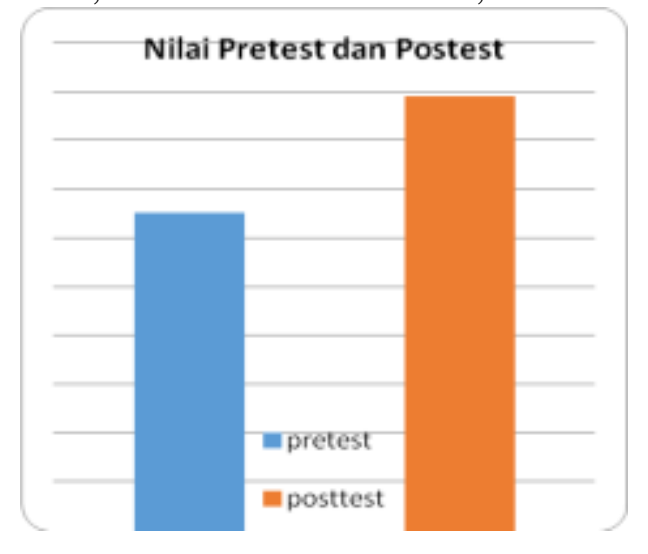

Gambar 1. Diagram Nilai Pretest Dan Posttest Siswa Kelas II 
Setelah dilakukan pretes terhadap 5 soal tentang penjumlahan dan pengurangan siswa disajikan cara membaca manik pada sempoa aritmatika. Komponen yang ada pada sempoa, tiang, manik, kolom nilai, garis nilai serta menghitung nilai pada bilangan satuan, puluhan dan ratusan melalui video pada papan tulis seperti gambar berikut:

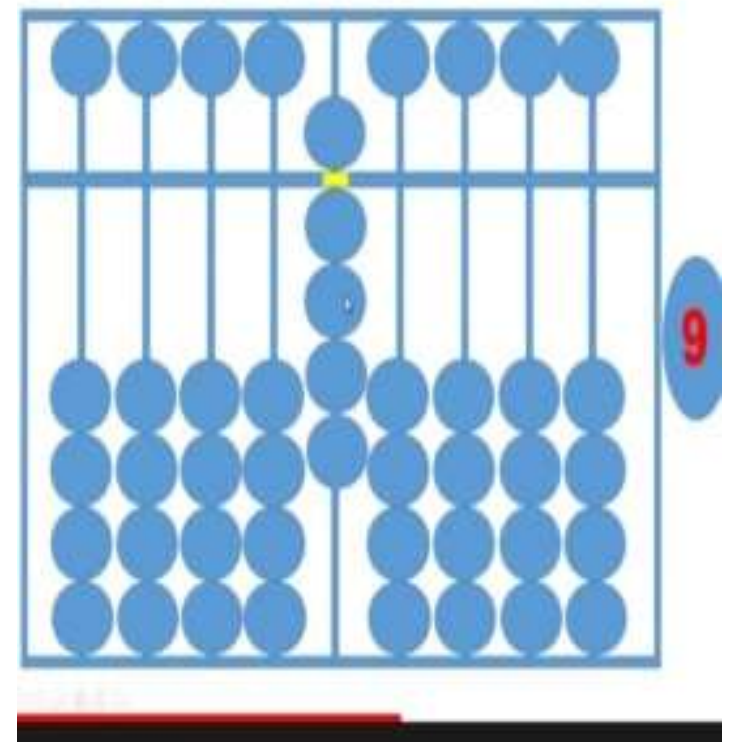

Gambar 2. Pengenalan Manik Sempoa melalui tayangan video di papan tulis

Langkah pertama siswa diajarkan unutk meng "nol" kan sempoa. Dengan memposisikan sempoa dengan benar dan tidak mendekatkan manik pada garis nilai. Penggunaan dimulai dari tiang tengah sebagai tiang satuan. Jika mundur ke arah kiri menjadi nilai puluhan dan ke kiri lagi menjadi nilai ratusan dan begitu seterusnya. Sempoa ini terdiri dari 5 manis pada setiap tiangnya. Empat manik pada bagian bawah bernilai satu dan satu manik di atas bernilai lima. Diantara kelompok manis atas dan bawah dibatasi oleh garis nilai. Kolom manik mewakili nilai "tempat". Untuk menghitung penjumlahan dapat dilakukan dengan menaikkan sebuah manik-manik sesuai dengan jumlah yang diminta dengan contoh sebagai berikut:

a. Untuk membuat nilai empat dapat menaikkan manik pada bagian bawah di kolom satuan sebanyak empat manik dengan menggunakan ibu jari. b. Untuk membuat nilai lima dapat menggunakan telunjuk dengan gerakan kebawah sehingga manik berada pada garis nilai.

c. Untuk membuat nilai delapan dapat menggerakkan manik atas dan bawah yaitu manik atas bernilai 5 dan manik bawah bernilai 3 dengan menaikkan 3 buah maniknya secara bersamaan.

Setelah pemateri menjelaskan membaca manik pada sempoa siswa diajak untuk mengerjakan latihan membaca manik sempoa yang ada pada modul kegiatan di bawah ini adalah gambar kegiatan tersebut:

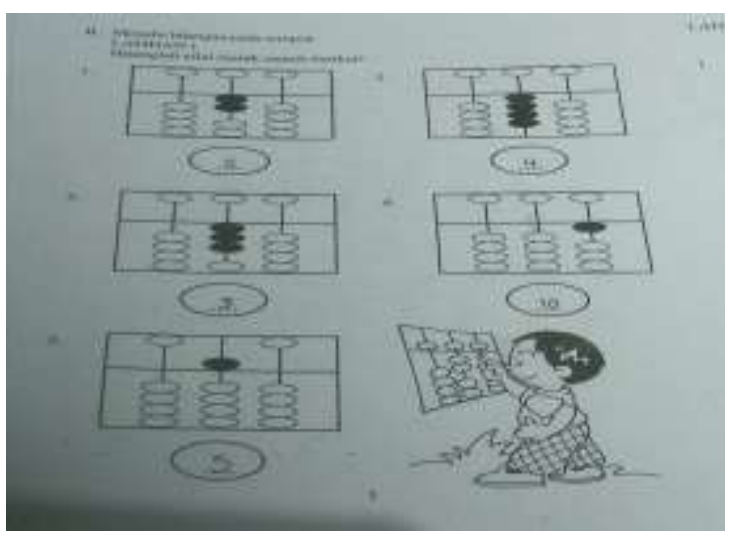

Gambar 3. Siswa menyelesaikan soal yang ada pada Modul latihan

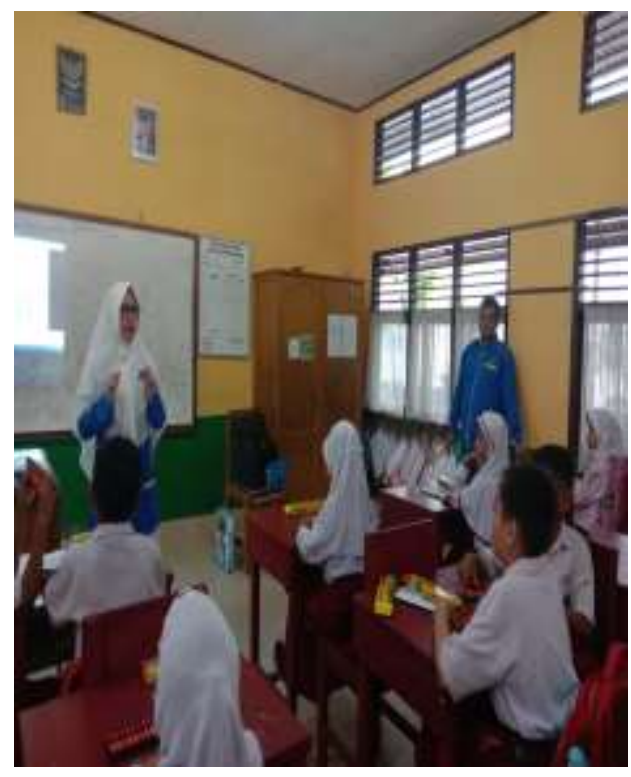

Gambar 4. Mengenalkan Manik Sempoa 
Anak-anak memperhatikan dengan seksama karena mereka baru menemui alat berhitung sempoa aritmatika. Siswa mulai membiasakan diri dengan sempoa dan mulai membaca manik sempoa yang ada di tangan. Mulai mengumpulkan sempoa, menghitung satuan, puluhan dan ratusan.

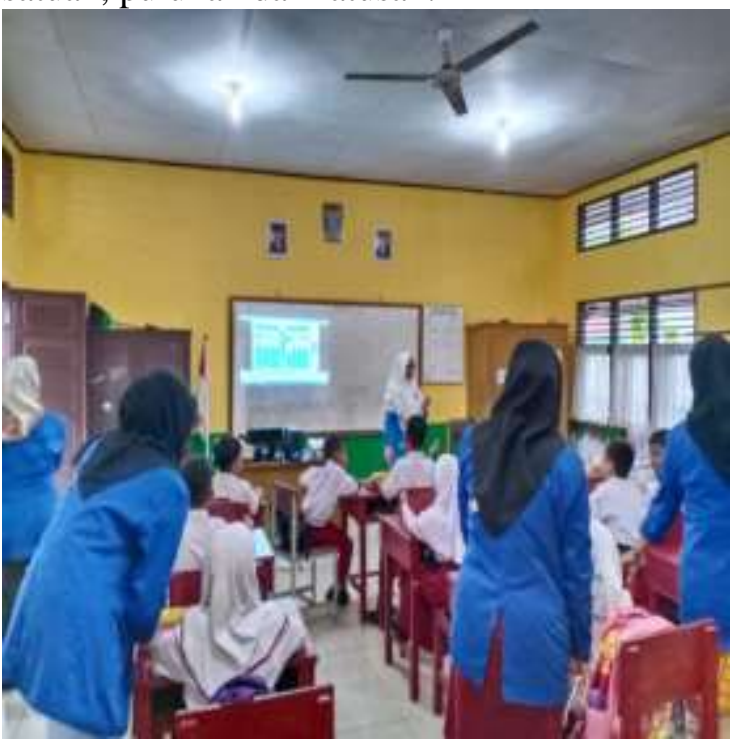

Gambar 5. Siswa diarahkan untuk Latihan dengan Sempoa dan Modul yang dibimbing oleh Pemateri

Siswa mulai latihan membaca manik dengan sempoa dan mengerjakan latihan yang ada pada modul. Setelah siswa mengerjakan 3 sesi latihan membaca manik selanjutnya dilanjutkan dengan sesi penjumlahan bilangan satuan, puluhan dan ratusan. Pada sesi ini siswa membutuhkan waktu yang lama karena masih belum terbiasa menggunakan sempoa.

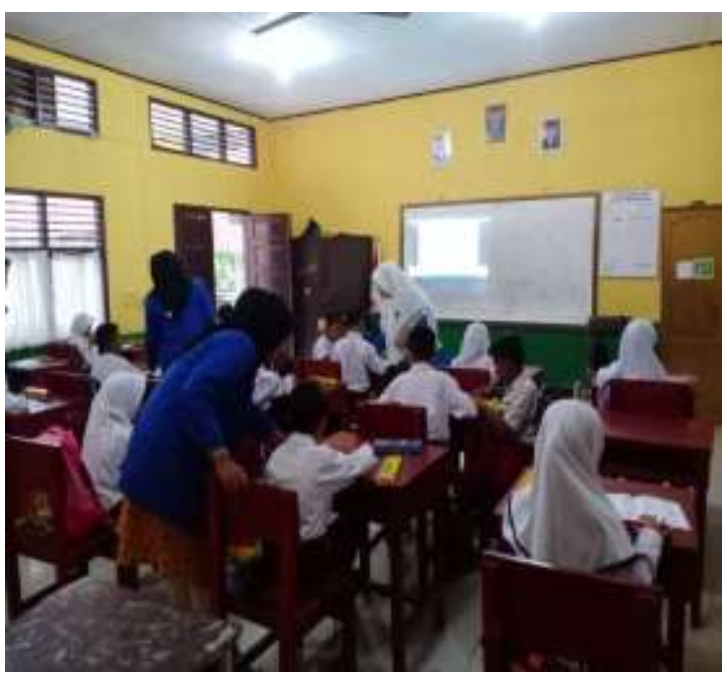

Gambar 6. Siswa mulai mengerjakan latihan penjumlahan
Siswa mengerjakan latihan pada modul tentang penjumlahan. Penjumlahan berurutan sebanyak 3 buah bilangan dapat diselesaikan oleh siswa. Selain itu, secara tidak sadar ada salah satu siswa berhitung secara manual dan kakak pemateri langsung memberikan arahan untuk menggunakan sempoa. Siswa masih belum terbiasa menggunakan alat sempoa. Hal ini menjadi kendala siswa dalam meningkatkan kemampuannya. Siswa hendaknya banyak berlatih dengan sempoa agar dapat menambah kemampuan. Salah satu jawaban siswa dapat dilihat pada gambar di bawah ini:

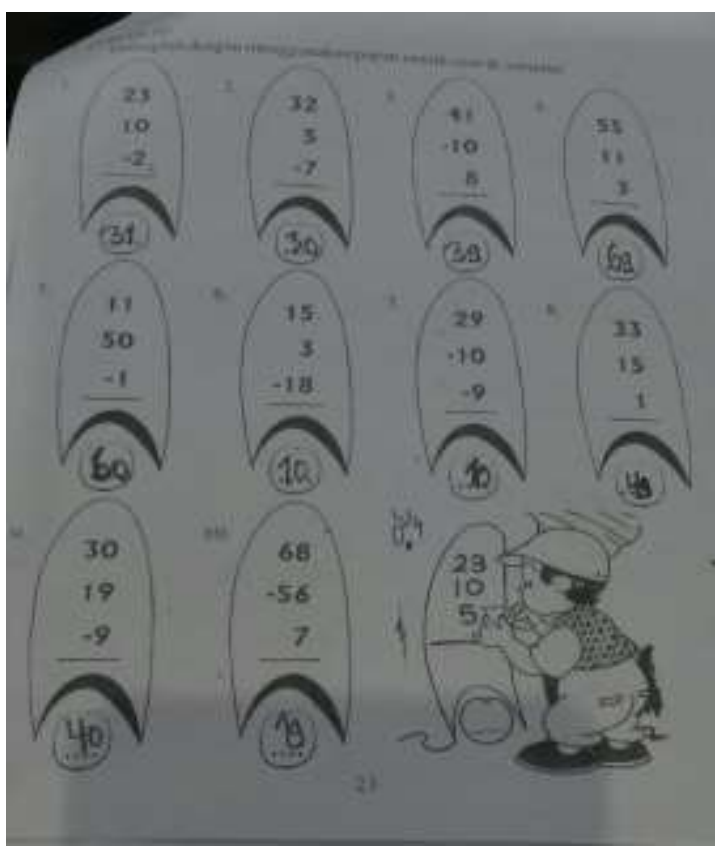

Gambar 7. Hasil Pengerjaan Siswa pada Operasi Campuran Puluhan

Sesi hari Kedua adalah siswa diberikan cara penggunaan sempoa dengan operasi pengurangan. Siswa diarahkan untuk membiasakan menggunakan telunjuk dalam melakukan pengurangan. Siswa dapat melakukannya dengan baik. Pada sesi ini 20 menit pertama pemateri memberikan materi teknik dasar untuk mengurangi adalah dimulai dari depan lalu berlanjut ke belakang hingga akhirnya hasil bisa didapat dengan mudah. 


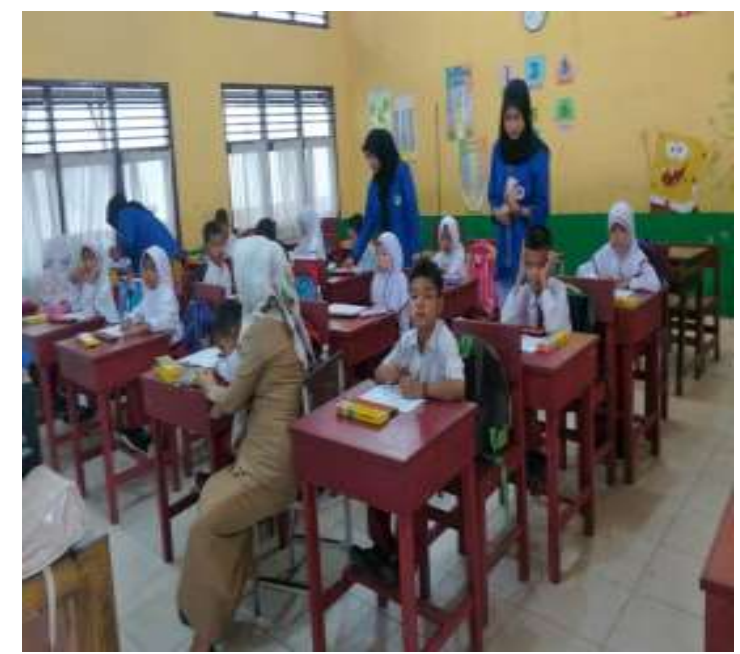

Gambar 8. Siswa Menyelesaikan Soal Pengurangan

Pada sesi pengerjaan modul pengurangan siswa sudah mulai terbisa menggunakan sempoa dan sudah dapat menghitung dengan benar harga yang ada di manik sempoa. Dan 10 menit terakhir dilakukan posttest.

Untuk lebih jelas rangkuman umpan balik pemahaman peserta terhadap materi sebagai berikut:

Tabel 1. Rekapitulasi Umpan balik pemahaman siswa terhadap materi

\begin{tabular}{|c|c|c|}
\hline Umpan Balik & $\begin{array}{c}\text { Jumlah } \\
\text { Orang }\end{array}$ & Persentase \\
\hline Pemahaman siswa & 22 & \\
\hline 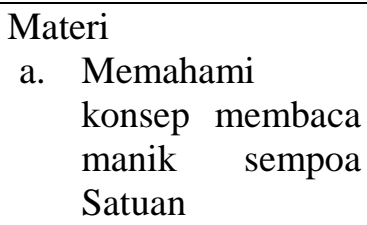 & 22 & $100 \%$ \\
\hline $\begin{array}{l}\text { b. Memahami } \\
\text { konsep membaca } \\
\text { manik sempoa } \\
\text { Puluhan }\end{array}$ & 22 & $100 \%$ \\
\hline $\begin{array}{ll}\text { c. Memahami } \\
\text { konsep membaca } \\
\text { manik rempoa } \\
\text { Ratusan }\end{array}$ & 22 & $100 \%$ \\
\hline $\begin{array}{l}\text { d. Penjumlahan } \\
\text { dengan Sempoa }\end{array}$ & 20 & $90 \%$ \\
\hline
\end{tabular}

Dari umpan balik tersebut, diperoleh hasil bahwa kemampuan siswa bertambah hal ini berdasarkan hasil dari pemahaman siswa dalam mengisi soal posttest yang dianalisis pada tabel umpan balik. Siswa dapat memahami konsep membaca manik sempoa satuan, puluhan, dan ratusan. Menurut Charleswoth dan Lind (Widjayatri, 2016) menjelaskan bahwa siswa yang berada pada usia dini merupakan periode saat anak mengambangkan konsep dasar mereka. Setelah siswa memahami konsep membaca manik siswa juga telah memahami penjumlahan dan pengurangan dengan rerata persentase $90 \%$. Dengan diperoleh hasil tersebut menunjukkan bahwa dengan penggunaan media sempoa dapat meningkatkan kemampuan berhitung siswa. Hal ini sejalan dengan penelitian Sulistiyono (Yogyakarta, 2016) bahwa penggunaan media sempoa efektif dapat meningkatkan kemampuan operasi hitung pengurangan.

Manfaat lain yang dapat dirasakan siswa adalah pembelajaran matematika menjadi menyenangkan, mengoptimalkan daya imajinasi dan kreativitas, dan koordinasi antara tangan dan otak lebih baik. Hal ini sependapat dengan Khumaidah (Fauziyah, Yuliati, \& Nuriman, 2017) menyatakan bahwa belajar sempoa memiliki kelebihan yaitu dapat menyeimbangkan otak kiri dengan otak kanan, meningkatkan konsentrasi dan meningkatkan rasa percaya diri. Sejalan dengan itu, menurut (Nurmalasari, 2013) bahwa penggunaan media pembelajaran sempoa memiliki pengaruh yang signifikan terhadap kreativitas.

Selain itu,, untuk pengabdian ini hendaknya ditambah durasi waktu dalam penyampaian karena mengingat siswa masih pada kelas rendah pada operasi pengurangan. Siswa masih banyak berlatih menggunakan alat sempoa ini.

\section{KESIMPULAN}

Kesimpulan yang dapat diambil dari kegiatan ini adalah:

a. Kemampuan berhitung siswa menjadi meningkat

b. Pembelajaran matematika menjadi menyenangkan.

c. Dapat meningkatkan daya imajinasi dan kreativitas serta koordinasi antara tangan dan otak lebih baik. 


\section{UCAPAN TERIMA KASIH}

kepada:

Ucapan terima kasih kami sampaikan

a. Yayasan Lembaga Pendidikan (YLPI)

Kota Dumai.

b. Sekolah Tinggi Teknologi Dumai.

c. LPPM Sekolah Tinggi Teknologi Dumai

d. Ibu Kepala sekolah SDN 001 Rimba Sekampung Sulasteri, S.Pd

e. Para Perserta yang berpartisipasi dalam pelatihan yaitu siswa dan siswi kelas II Sekolah SDN 001 Rimba Sekampung.

\section{DAFTAR PUSTAKA}

Anugrahana, A. (2019). Pengembangan Modul Sempoa Sebagai Alternatif Dalam Mata Kuliah Inovatif Matematika. Jurnal Cendekia: Jurnal Pendidikan Matematika, 3(2), 462470.

https://doi.org/10.31004/cendekia.v3i 2.130

Dianto, R. (2018). Penggunaan Sempoa Untuk Meningkatkan Mental Aritmetika Siswa SD pada Pembelajaran Kabataku. Jurnal Equation: Teori Dan Penelitian Pendidikan Matematika, 1(2), 145. https://doi.org/10.29300/equation.v1i 2.2296

Fatmawati, N. (2014). Peningkatan Kemampuan Berhitung Melalui Pendekatan Realistic Mathematic Education. Jurnal Pendidikan Usia Dini, 8(2), 325-336. Retrieved from http://journal.unj.ac.id/unj/index.php/j pud/article/view/3597

Fauziyah, P. R., Yuliati, N., \& Nuriman, N. (2017). Peningkatan Kemampuan Berhitung Permulaan Melalui Metode Demonstrasi dengan Media Sempoa Pada Anak Kelompok B1 di TK Amelia Kecamatan Sumbersari Kabupaten Jember Tahun Pelajaran 2016/2017. Jurnal Edukasi, 4(3), 45. https://doi.org/10.19184/jukasi.v4i3.6 301
Nurfiyanti, D. (2019). Efektivitas Media Sempoa Dalam Meningkatkan Keterampilan Berhitung Siswa Pada Mata Pelajaran Matematika Di Sd Negeri 2 Borobudur Keterampilan Berhitung Siswa Pada Mata Pelajaran Matematika Di Sd Negeri 2 Borobudur.

Nurmalasari, I. (2013). Kelas Ii Sdn Ii Karangrejo Tulungagung Skripsi Sekolah Tinggi Agama Islam Negeri ( Stain) Tulungagung.

Romlah, M., Kurniah, N. \& W. (2016). Peningkatan Kemampuan Berhitung Anak Melalui Kegiatan Bermain Sempoa. 1(2), 72-77.

Universitas Negeri Semarang. Lembaga Pengabdian Kepada Masyarakat., S. I., \& Wijayanti, S. H. (2008). Jurnal abdimas: LPM Universitas Negeri Semarang. Jurnal Abdimas, 22(2), 227-234. Retrieved from https://journal.unnes.ac.id/nju/index.p hp/abdimas/article/view/8983/8748

Widjayatri, D. (2016). Peningkatan Kemampuan Berhitung Melalui Pendekatan Pembelajaran Aktif Inovatif Kreatif Efektif Dan Menyenangkan (Paikem). Jurnal Cakrawala, 1(1), 6-8. https://doi.org/10.1017/CBO9781107 415324.004

Yogyakarta, U. N. (2016). Efektivitas Media Sempoa Terhadap Kemampuan Operasi Hitung Pada Siswa Tunarungu. Jurnal Widia Ortodidaktika, 5(11), 1169-1179. 